\title{
Toxicity, Phytochemical Composition, and Enzyme Inhibitory Activities of Some Indigenous Weed Plant Extracts in Fruit Fly, Drosophila melanogaster
}

\author{
Bushra Riaz, ${ }^{1}$ Muhammad Kashif Zahoor $\mathbb{D}^{1},{ }^{1}$ Muhammad Asif Zahoor, \\ Humara Naz Majeed, ${ }^{3}$ Irum Javed, ${ }^{3}$ Aftab Ahmad, ${ }^{4}$ Farhat Jabeen, ${ }^{1}$ \\ Muhammad Zulhussnain, ${ }^{1}$ and Kishwar Sultana ${ }^{1}$ \\ ${ }^{1}$ Department of Zoology, Government College University Faisalabad, Faisalabad, Pakistan \\ ${ }^{2}$ Department of Microbiology, Government College University Faisalabad, Faisalabad, Pakistan \\ ${ }^{3}$ Department of Biochemistry, Government College Women University Faisalabad, Faisalabad, Pakistan \\ ${ }^{4}$ Centre of Department of Biochemistry/US-Pakistan Center for Advance Studies in Agriculture and Food Security (USPCAS-AFS), \\ University of Agriculture Faisalabad, Faisalabad, Pakistan
}

Correspondence should be addressed to Muhammad Kashif Zahoor; kashif.zahoor@gcuf.edu.pk

Received 4 October 2017; Revised 13 February 2018; Accepted 26 February 2018; Published 12 April 2018

Academic Editor: Gianni Sacchetti

Copyright (C) 2018 Bushra Riaz et al. This is an open access article distributed under the Creative Commons Attribution License, which permits unrestricted use, distribution, and reproduction in any medium, provided the original work is properly cited.

\begin{abstract}
Drosophila melanogaster being used as model organism is considered as pest of homes, restaurants, and fruit markets. The damaged fruits are also reported to serve as a carrier for various diseases. The current study was designed to evaluate the toxicity of petroleum extract of some weed plants, namely, Euphorbia prostrata, Parthenium hysterophorus, Fumaria indica, Chenopodium murale, and Azadirachta indica, against D. melanogaster. Mortality at 10, 20, and 30\% concentrations after 24 and 48 hours was found comparatively low. E. prostrata caused high mortality $(51.64 \%)$ at $30 \%$ concentration and was found more toxic ( $\mathrm{LC}_{50} 27.76$; $P$ value 0.00$)$ after 72 hours. A. indica showed high $L_{50}$ value ( $P$ value 0.15$)$ compared to other weed plants. The combination of $E$. prostrata and Bti showed highest mortality $\left(100 \% ; L_{50} 12.49 ; P\right.$ value 0.00$)$ after 72 hours. Similarly, the same combination caused maximum reduction in the activity of AChE, AcP, AkP, $\alpha$-Carboxyl, and $\beta$-Carboxyl enzymes. Phytochemical analysis showed the presence of flavonoids, saponins, tannins, steroids, cardiac glycosides, alkaloids, anthraquinones, and terpenoids. FTIR analysis of E. prostrata showed the presence of phenolic compounds. It is suggested that further studies are needed in order to incorporate weed plant extracts in combination with Bti for the management of fruit flies.
\end{abstract}

\section{Introduction}

Fruit flies are considered as serious pests and the cost of infestation has been estimated to millions of dollars annually worldwide $[1,2]$. Many species of fruit flies such as Bactrocera and Drosophila are reported to attack different fruits particularly mango and guava in Pakistan. This causes a major economic threat because of rejection of consignments of mangoes exported at international level [3].

Infestation due to fruit flies is manifested initially by scars in the fruit surface left by stinging through ovipositor of females. As eggs hatch time is very short approximately one day, larvae in a little while start feeding inside the fruit.
Within 2 or 3 days, the fruit begins to collapse around the feeding site. Thereafter, mold and invasion by secondary pests may aid to further damage [3]. D. melanogaster being a versatile model in various biological studies also acts as a fruit pest in nature. It is also acting as a vector of lifethreatening pathogen, Staphylococcus aureus [4]. Biological control of fruit flies is mainly focused on predacious and parasitic natural enemies, and it has played an essential role in ecological conservation as well as biological control programs. Besides natural enemies, microorganisms and plant extracts have also been used for better management of flies [5]. In addition, fungi and bacteria are also reported to produce reasonable results [6]. 
Weeds are being investigated for their phytochemical, pharmacological, and biological properties $[3,7,8]$. Recently, insecticidal properties of weeds have been reported in many insects [9-13]. Euphorbia prostrata is an annual herb used for fever, for bleeding hemorrhoids, and against various abdominal diseases [14]. It is also used as an antidote for venomous bites of wasps and scorpions. Chenopodiastrum murale (L.) is widespread noxious herbaceous weed which is reported to show antioxidant and antibacterial activities [15]. The chemical composition showed that extract from C. murale had essential oils, flavonoids, sterols, alkaloids, and coumarins which exhibited antibacterial, antifungal, phytotoxic, and insecticidal activities [7, 8]. Parthenium hysterophorus weed is widely distributed in America, Asia, Africa, and Australia. Its health benefits include remedy for skin inflammation, rheumatic pain, diarrhoea, urinary infections, dysentery, malaria, and neuralgia. It contains various allelochemicals such as glycoside parthenin, hysterin, ambrosin, flavonoids, sitosterol, and some unidentified alcohols $[16,17]$. Subsequently, the use of $P$. hysterophorus as biopesticides has also been reported [16]. Fumaria indica (Hausskn.) (Fumariaceae) is a small, scandent, branched, annual herb and locally known as "Shahtra." It is regarded as laxative, diuretic, and diaphoretic. It is beneficial in fever, influenza, dyspepsia, liver disorders, and skin infections and also reported as blood purifier. It is also used in syphilis, scrofula, leprosy, constipation, ague, and jaundice. It contains a number of compounds including seven alkaloids. Importantly, it has been reported as safe during acute and chronic toxicity studies [18].

Toxicity of various insecticides including insecticidal activity of alkaloids has been reported in $D$. melanogaster $[12,19,20]$. A. indica (Neem) extract has also been reported for its toxicological evaluations in comparison to insecticides in D. melanogaster [21]. However, no work has been reported yet in Pakistan to control fruit flies through using weed plant extracts. Thus, taking advantage of $D$. melanogaster as both an easy model to rear and a fruit pest as well in order to devise a control program for other fruit flies too, the present study was designed to use Azadirachta indica, Euphorbia prostrata, Parthenium hysterophorus, Fumaria indica, and Chenopodium murale L. for their toxicological studies in $D$. melanogaster. Bti was also used along with the extracts as a potent controlling agent. This study serves as the first research work which is conducted using weed extracts against fruit flies in Pakistan.

\section{Materials and Methods}

Research work was performed in the Entomology Lab. Government College University Faisalabad (GCUF), to investigate the efficacy of the selected weed plants against $D$. melanogaster. The fruit fly, D. melanogaster, was collected from GCUF and reared using artificial food (Agar, Yeast, Banana, Maltose, Cornmeal, and Sodium Benzoate) [22, 23].

2.1. Preparation of Plant Extracts. Common weeds were collected from the rural area of Faisalabad city. Four weed plants extracts and one $A$. indica (Neem plant) extract was used (Table 1). The whole plants were washed thoroughly with clean water and then shade dried for 7-8 days [11]. Dried plants were again oven dried at 60-degree centigrade for 20 minutes. Plants were powdered using grinder machine into fine powder. For oil extract, $100 \mathrm{~g}$ of ground sieved sample and $300 \mathrm{ml}$ of petroleum ether (40-60\%) were mixed in 1:3 in conical flask. These flasks were fixed on rotary machine at $220 \mathrm{rpm}$ for 24 hours. After this the plant extract was filtered through Whatman No. 1 filter paper. From stock solution, working solutions of 10,20, and 30\% concentrations were prepared for each plant $[11,13]$.

2.2. Mortality Bioassay. Mortality bioassay was conducted under standard conditions (Temp. $25^{\circ} \mathrm{C}$ and $\mathrm{RH} 80 \%$ ) using five plant extracts with three different concentrations. In each trial, 20 third instar larvae of Drosophila were introduced containing feed and plant extracts with $10 \%$ to $30 \%$ concentrations. For control, only feed and petroleum ether with the corresponding concentration of extracts were used. Mortality of Drosophila larvae was observed after time interval of 24, 48, and 72 hours. Each concentration was replicated three times. Further Bacillus thuringiensis israelensis (Bti) was used to compare its efficacy with plant extract. From the observed data percentage mortality was counted by using the following formula [24].

$$
\begin{aligned}
\text { Percentage mortality }= & \frac{\text { number of dead larvae }}{\text { number of larvae tested }} \\
& \times 100
\end{aligned}
$$

\subsection{Enzyme Assay}

2.3.1. Preparation of Whole Body Homogenate. For enzymatic estimation, the larvae of $D$. melanogaster were washed thoroughly with distilled water and the adhering water was removed by using bloating paper. The larvae were homogenized using ice-cold sodium phosphate buffer $(20 \mathrm{mM}$, $\mathrm{pH}$ 7.0) with the help of Teflon hand homogenizer. Then, the homogenate was centrifuged at $8000 \times \mathrm{g}$ and $4^{\circ} \mathrm{C}$ for 20 minutes and supernatant was used for the estimation of Esterases or Phosphatases. Solutions and glassware used for homogenization were kept at $4^{\circ} \mathrm{C}$ prior to use, and the homogenates were held on ice until used for various assays [25].

\subsection{Quantitative Determination of Esterases and Phosphatases}

(1) Estimation of Acetylcholinesterase Activity. In the $50 \mu \mathrm{l}$ of enzyme solution, $50 \mu \mathrm{l}$ of acetylcholine chloride $(2.6 \mathrm{mM})$ as a substrate and $1 \mathrm{ml}$ of sodium phosphate buffer $(20 \mathrm{mM}, \mathrm{pH}$ 7.0) were added. It was incubated at $25^{\circ} \mathrm{C}$ for $5 \mathrm{mins}$. Then $400 \mu \mathrm{l}$ of $0.3 \%$ Fast blue B salt was added to stop reaction. Blank and sample were run through spectrophotometer. Optical density (OD) was recorded at $405 \mathrm{~nm}$ [25].

(2) Estimation of Carboxylesterase Activity. The activity of $\alpha$-carboxylesterase and $\beta$-carboxylesterase was measured in larvae [26]. In $50 \mu$ l enzyme solution (homogenates), $1 \mathrm{ml}$ of sodium phosphate buffer $(20 \mathrm{mM}, \mathrm{pH} 7.0)$ and $50 \mu \mathrm{l}$ of 
TABLE 1: List of weed plants used during the study.

\begin{tabular}{lcccc}
\hline Number & Scientific name & Common name & Family name & Used parts \\
\hline 1 & Euphorbia prostrata & Bakkar booti & Euphorbiaceae & Whole plant \\
2 & Chenopodium murale L. & Kurand & Amaranthaceae & Whole plant \\
3 & Azadirachta indica & Neem & Meliaceae & Whole plant \\
4 & Fumaria indica & Shahtra & Papaveraceae & Whole plant \\
5 & Parthenium hysterophorus & White top & Asteraceae & Whole plant \\
\hline
\end{tabular}

each $\alpha$-naphthyl acetate and $\beta$-naphthyl acetate (substrate) were added separately to determine the activities of $\alpha$ carboxylesterase and $\beta$-carboxylesterase, respectively. The solutions were incubated at $30^{\circ} \mathrm{C}$ for 20 mins. After incubation, $400 \mu \mathrm{l}$ of freshly prepared $0.3 \%$ Fast blue B in $3.3 \%$ SDS was added in each reaction mixture to stop the enzymatic reaction and the color was allowed to develop for $15 \mathrm{~min}$ at $20^{\circ} \mathrm{C}$. Blank and sample were run on spectrophotometer. Optical density (OD) was recorded at 430 and $590 \mathrm{~nm}$ for $\alpha$ carboxylesterase and $\beta$-carboxylesterase, respectively [25].

(3) Estimation of Acid and Alkaline Phosphatase Activity. The level of acid and alkaline phosphatases was measured in larvae [27]. The acid phosphatase activity was estimated by mixing $50 \mu \mathrm{l}$ larval homogenate with $50 \mu \mathrm{l}$ sodium phosphate buffer $(50 \mathrm{mM}, \mathrm{pH} 7.0)$ and $100 \mu \mathrm{l}$ of $20 \mathrm{mM}$ p-nitrophenyl phosphate (substrate). For the estimation of alkaline phosphatase activity, $50 \mu \mathrm{l}$ larval homogenate was mixed with $50 \mu \mathrm{l}$ Tris HCl buffer ( $50 \mathrm{mM}, \mathrm{pH} 9.0)$ and $100 \mu \mathrm{l}$ of $20 \mathrm{mM} \mathrm{p}$ nitrophenyl phosphate (substrate). After that, both solutions of acid phosphatase and alkaline phosphatase were incubated at $37^{\circ} \mathrm{C}$ for 15 mins in water bath, and the enzymatic reaction was stopped by adding $0.5 \mathrm{~N} \mathrm{NaOH}$ solution. The absorbance (OD) of the resulting clear supernatants of sample and blank was recorded at $440 \mathrm{~nm}$ [25].

The percentage inhibition of the enzyme activity by the test extracts was calculated as follows:

$\%$ enzyme inhibition

$$
\begin{aligned}
= & \frac{\text { OD of control larvae }- \text { OD of treated larvae }}{\text { OD of control larvae }} \\
& \times 100
\end{aligned}
$$

2.5. Preliminary Phytochemical Screening of the Plant Extracts. The plant extracts prepared by using the petroleum ether as solvent as mentioned above were concentrated by evaporation and stored at $4^{\circ} \mathrm{C}$ in air tight containers for further experimental studies. Qualitative phytochemical analysis of plant extracts (petroleum ether) was carried out by using standard procedures [28-30].

2.6. Test for Alkaloids. One $\mathrm{ml}$ of $1 \% \mathrm{HCl}$ was added to $3 \mathrm{ml}$ of plant extract in a test tube and was treated with few drops of Meyer's reagent (potassium mercuric iodine solution). Formation of white yellowish turbidity or precipitate indicates the presence of alkaloids [31].
2.7. Test for Terpenoids (Salkowski Test). Five ml plant extract was taken in test tube with $2 \mathrm{ml}$ of chloroform $\left(\mathrm{CHCl}_{3}\right)$, and $3 \mathrm{ml}$ concentrated $\mathrm{H}_{2} \mathrm{SO}_{4}$ was carefully added to form a layer. Reddish brown color at interface indicated the presence of terpenoids [28].

2.8. Test for Saponins (Foam Test). In a test tube, $0.5 \mathrm{ml}$ of plant extract was shaken vigorously with $2 \mathrm{ml}$ of distilled water to obtain a stable persistent froth. Foamy lather, if it persists for 10 minutes, indicates the presence of saponins $[30,32]$.

2.9. Test for Flavonoids. Few drops of sodium hydroxide $(\mathrm{NaOH})$ solution were added to the extract in a test tube. A yellow coloration, which becomes colorless on addition of dilute acid, indicated the presence of flavonoids [32, 33].

2.10. Test for Tannins. Half $\mathrm{ml}$ of crude extract was taken in a test tube, and $1 \mathrm{ml}$ of distilled water and 1-2 drops of ferric chloride solution were added into it. Appearance of blue and greenish black coloration was an indication of gallic tannins and catecholic tannins, respectively [34].

Gelatin Test. To the test solution were added $1 \mathrm{ml}$ of $1 \%$ gelatin solution and $1 \mathrm{ml}$ of $10 \% \mathrm{NaCl}$, and white precipitate of gelatin indicates the presence of tannins $[29,30]$.

2.11. Test for Cardiac Glycosides (Keller-Killani Test). In a test tube, $5 \mathrm{ml}$ of plant extract, $2 \mathrm{ml}$ of glacial acetic acid, and few drops of ferric chloride solution were added. $2 \mathrm{ml}$ of concentrated $\mathrm{H}_{2} \mathrm{SO}_{4}$ was added along the side of test tube. Formation of a brown ring at the interface indicated the presence of glycosides [29].

\subsection{Test for Phenols}

Ferric Chloride Test. 3-4 drops of ferric chloride solution were added to crude extract in test tube and shaken well. Formation of bluish black color indicated the presence of phenol [29].

2.13. Test for Quinones. To the $2 \mathrm{ml}$ of test substance conc. $\mathrm{H}_{2} \mathrm{SO}_{4}$ was added and shaken well for $5 \mathrm{~min}$, and appearance of red color indicates the presence of quinone [29].

2.14. Test for Steroids Liebermann Test. $10 \mathrm{ml}$ of chloroform was added to the test solution and then filtered. In a test tube containing $2 \mathrm{ml}$ filtrate, $2 \mathrm{ml}$ of acetic anhydride and few 
TABLE 2: Mean mortality of Drosophila melanogaster larvae after 72 hours of exposure to different concentration of weed plants extracts.

\begin{tabular}{|c|c|c|c|}
\hline \multirow{2}{*}{ Plant name } & \multicolumn{3}{|c|}{ Concentration } \\
\hline & $10 \%$ & $20 \%$ & $30 \%$ \\
\hline $\begin{array}{l}\text { Euphorbia prostrata } \\
(F=13.30 ; \text { d.f. }=2 ; P<0.05)\end{array}$ & $34.06 \pm 5.45^{\mathrm{a}}$ & $42.70 \pm 5.28^{\mathrm{ab}}$ & $51.64 \pm 6.25^{c}$ \\
\hline $\begin{array}{l}\text { Chenopodium murale } \\
(F=13.46 ; \text { d.f. }=2 ; P<0.05)\end{array}$ & $25.38 \pm 5.02^{\mathrm{a}}$ & $33.54 \pm 5.44^{\mathrm{a}}$ & $40.80 \pm 6.17^{\mathrm{b}}$ \\
\hline $\begin{array}{l}\text { Azadirachta indica } \\
(F=12.14 ; \text { d.f. }=2 ; P<0.05)\end{array}$ & $27.49 \pm 6.36^{\mathrm{a}}$ & $34.66 \pm 4.99^{\mathrm{b}}$ & $42.45 \pm 5.33^{\mathrm{b}}$ \\
\hline $\begin{array}{l}\text { Fumaria indica } \\
(F=10.77 \text { d.f. }=2 ; P<0.05)\end{array}$ & $27.26 \pm 5.70^{\mathrm{a}}$ & $35.97 \pm 5.76^{\mathrm{b}}$ & $43.92 \pm 5.56^{\mathrm{b}}$ \\
\hline $\begin{array}{l}\text { Parthenium hysterophorus } \\
(F=9.82 \text {; d.f. }=2 ; P<0.05)\end{array}$ & $26.15 \pm 4.19^{\mathrm{a}}$ & $32.28 \pm 5.65^{\mathrm{a}}$ & $41.87 \pm 5.42^{b}$ \\
\hline
\end{tabular}

$\mathrm{a}, \mathrm{b}, \mathrm{c}$, and ab: means sharing the same letter within each treatment are not statistically different.

TABLE 3: Toxicity of weed plant extracts against Drosophila melanogaster larvae after 72 hours of exposure.

\begin{tabular}{llcccc}
\hline Plants & $N$ & LC $_{50}$ (lower value \pm upper value) & Slope \pm SE & $X^{2}$ & $P$ value \\
\hline Euphorbia prostrata & 20 & $27.76(21.47 \pm 55.12)$ & $0.0231259 \pm 0.0090030$ & 0.0009525 & 0.00 \\
Chenopodium murale L. & 20 & $39.68(29.66 \pm 126.75)$ & $0.0222512 \pm 0.0092747$ & 0.0587030 & 0.01 \\
Azadirachta indica & 20 & $39.50(29.05 \pm 180.91)$ & $0.0205005 \pm 0.0092029$ & 0.0193744 & 0.15 \\
Fumaria indica & 20 & $36.22(27.70 \pm 94.38)$ & $0.0230412 \pm 0.0091880$ & 0.0220428 & 0.00 \\
Parthenium hysterophorus & 20 & $39.73(29.68 \pm 127.85)$ & $0.0221777 \pm 0.0092583$ & 0.0793358 & 0.00 \\
\hline
\end{tabular}

drops of con. $\mathrm{H}_{2} \mathrm{SO}_{4}$ were added. Formation of blue green ring indicates the presence of steroids [33].

\subsection{Fourier Transform Infrared Spectroscopy (FTIR) Analysis.} The E. prostrata extract which showed highly significant results was examined by FTIR spectroscopy for the detection of the specific functional groups. The extracts prepared in $\mathrm{n}$-Hexane were frozen at $-80^{\circ} \mathrm{C}$ followed by lyophilization. Infrared absorption spectrum of the lyophilized extract was recorded on a FTIR spectrophotometer (Alpha, Bruker, California, USA) in the region 4000 to $500 \mathrm{~cm}^{-1}[35,36]$.

2.16. Statistical Analysis. After calculating percentage mortality, the data for different concentrations were subjected to Probit Analysis program (version 1.5) to determine the $\mathrm{LC}_{50}$. ANOVA was performed using Statistica 13.0 for windows. The means were separated through Tukey's HSD (Honest Significant Difference) test at a significance level of 0.05 . A value of $P<0.05$ was considered statistically significant.

\section{Results}

3.1. Mortality of Drosophila melanogaster Larvae. The mortality data of $D$. melanogaster larvae were observed at various concentrations and exposure time for five plants extracts (Table 2). E. prostrata showed high mortality (51.64\%) at 30\% concentration after 72 hours. Mortality at concentration of $10 \%, 20 \%$, and $30 \%$ after 24 and 48 hours is comparatively low compared to mortality after 72 hours. With C. murale, $40.80 \%$ mortality was observed at $30 \%$ after 72 hours of exposure time. Similarly, low mortality was found at concentration of 10,20 , and $30 \%$ after 24 and 48 hours compared to mortality after 72 hours of exposure (Table 2). A. indica showed $42.45 \%$ mortality at 72 hours, which is higher than mortality after 24 and 48 hours at concentration of 10,20 , and $30 \%$, respectively. F. indica showed $43.92 \%$ mortality at concentration of $30 \%$ after 72 hours which is the second highest mortality among all five extracts. Mortality at 10, 20, and 30\% concentration after 24 and 48 hours was comparatively less than the mortality after 72 hours. P. hysterophorus showed $41.87 \%$ mortality at concentration of $30 \%$ after 72 hours. It was found that increased concentration of weeds plant extracts caused high mortality (Table 2).

The $\mathrm{LC}_{50}$ value for all five extracts was decreased with the passage of time and the lowest $\mathrm{LC}_{50}$ value was observed after 72 hours as compared to 24 and 48 hours against D. melanogaster. The $\mathrm{LC}_{50}$ value after 72 hours for all five extracts is shown in Table 3. Among all five extracts, E. prostrata showed lowest $\mathrm{LC}_{50}$ value $(27.763 ; P$ value 0.00$)$ at 72 hours followed by Fumaria indica $\left(\mathrm{LC}_{50} 36.22 ; P\right.$ value 0.00$)$. Similarly, C. murale and $P$. hysterophorus showed $\mathrm{LC}_{50}=39.68$ $(P$ value 0.01$)$ and $L_{50}=39.73(P$ value 0.00$)$, respectively, while $A$. indica showed high $\mathrm{LC}_{50}$ value $(39.50 ; P$ value 0.15$)$ compared to other weed plants at 72 hours.

E. prostrata showed lowest $\mathrm{LC}_{50}$ values (Table 3 ) and, therefore, was further selected for combinatorial trials with $B t i$. The mean mortality of E. prostrata in combination with $B t i$ is shown in Table 4 . Bti solution and E. prostrata extract with the concentration of $250 \mathrm{ppm}$ showed highest mortality (100\%) after 72 hours. After 24 and 48 hours, 79\% and $96 \%$ mortality were observed, respectively. The mortality at $100 \mathrm{ppm}$ of Bti solution and E. prostrata extract was observed as 97 and $90 \%$ after 72 and 48 hours and $63 \%$ after 24 hours. The mortality shown by $50 \mathrm{ppm} B t i$ and E. prostrata extract 
TABLE 4: Mean mortality of Drosophila melanogaster larvae exposed to different concentrations of Bti and 30\% concentrations of Euphorbia prostrata.

\begin{tabular}{|c|c|c|c|c|}
\hline \multirow{2}{*}{ Number } & \multirow{2}{*}{ Concentrations } & \multicolumn{3}{|c|}{ Exposure time } \\
\hline & & $24 \mathrm{~h}$ & $48 \mathrm{~h}$ & $72 \mathrm{~h}$ \\
\hline 1 & Water + food & $4.44 \pm 1.76^{\mathrm{a}}$ & $9.00 \pm 2.92^{\mathrm{a}}$ & $18.18 \pm 3.36^{\mathrm{a}}$ \\
\hline 2 & Water $+B t i(50)+$ food & $6.67 \pm 2.22^{\mathrm{a}}$ & $12.74 \pm 3.25^{\mathrm{ab}}$ & $23.48 \pm 4.10^{\mathrm{a}}$ \\
\hline 3 & Euphorbia prostrata + water + food & $34.06 \pm 5.45^{\mathrm{a}}$ & $42.70 \pm 5.28^{\mathrm{ab}}$ & $51.64 \pm 6.25^{\mathrm{ab}}$ \\
\hline 4 & Euphorbia prostrate + Bti 10 ppm & $37.22 \pm 3.13^{\mathrm{a}}$ & $69.66 \pm 4.49^{\mathrm{b}}$ & $74.85 \pm 3.97^{\mathrm{b}}$ \\
\hline 5 & Euphorbia prostrate + Bti 50 ppm & $39.16 \pm 4.66^{\mathrm{a}}$ & $84.85 \pm 3.76^{\mathrm{b}}$ & $88.31 \pm 4.11^{\mathrm{b}}$ \\
\hline 6 & Euphorbia prostrata + Bti $100 \mathrm{ppm}$ & $63.50 \pm 4.23^{\mathrm{a}}$ & $90.94 \pm 2.98^{\mathrm{b}}$ & $97.54 \pm 0.56^{\mathrm{c}}$ \\
\hline 7 & Euphorbia prostrata + Bti $250 \mathrm{ppm}$ & $79.31 \pm 4.27^{\mathrm{a}}$ & $96.54 \pm 2.20^{\mathrm{b}}$ & $100.00^{\mathrm{c}}$ \\
\hline
\end{tabular}

a, b, c, and ab: means sharing the same letter within each treatment are not statistically different.

TABLE 5: Toxicity of different concentrations of Bti in combination with 30\% Euphorbia prostrata extract.

\begin{tabular}{lcccccc}
\hline Plants & Observation (hrs later) & $N$ & LC $_{50}$ (lower value \pm upper value) & Slope \pm SE & $X^{2}$ & $P$ value \\
\hline \multirow{3}{*}{ Bti+Euphorbia prostrate } & 24 & 20 & $75.53(46.32 \pm 101.12)$ & $0.0050047 \pm 0.0007578$ & 4.30 & 0.01 \\
& 48 & 20 & $34.96(22.60 \pm 84.90)$ & $0.0058996 \pm 0.0012481$ & 3.27 & 0.00 \\
& 72 & 20 & $12.49(8.02 \pm 70.72)$ & $0.0146966 \pm 0.0031638$ & 0.26 & 0.00 \\
\hline
\end{tabular}

${ }^{*} 10,50,100$, and 250 ppm concentrations of Bti.

was 88 and $84 \%$ after 72 and 48 hours, respectively, whereas $39 \%$ mortality was found after 24 hours. Low mortality among all concentrations of Bti solution and E. prostrata extract was shown by $10 \mathrm{ppm}$ of Bti and E. prostrata extract, that is, $74 \%$ after 72 hours, $69 \%$ after 48 hours, and $37 \%$ after 24 hours (mean mortality \%age). Different control trials were also performed in order to establish the mortality to exclude the effect of physical and/or any other factors. The overall results showed high mortality with combination of $E$. prostrata and Bti (250 $\mathrm{ppm})$ compared to the control groups (Table 4).

The results of lethal concentration of $50 \%$ mortality $\left(\mathrm{LC}_{50}\right)$ using the combination of E. prostrata and Bti along with control treatments are shown in Table 5. In combination with $B t i, E$. prostrata showed high toxicity with low $\mathrm{LC}_{50}$ values found to decrease with time. The $\mathrm{LC}_{50}$ value was 12.49 after 72 hours, whereas after 24 and 48 hours LC $_{50}$ values were found as 75.53 and 34.96 , respectively, at all exposure times. Moreover, it was found that mortality increased with an increase of E. prostrata and Bti concentrations (Tables 4 and 5).

The effect of these weed plant extracts on the enzymatic activity in $D$. melanogaster larvae was observed at various concentrations after 72 hours. The maximum decrease was observed at $30 \%$ concentration of extracts. E. prostrata induced a decrease in acetylcholine esterase, AcP, AkP, $\alpha$ Carboxyl, and $\beta$-Carboxyl enzymes by $53.7 \%, 33.3 \%, 23.6 \%$, $70.3 \%$, and $61.3 \%$, respectively, with $30 \%$ concentration. In addition, a decrease in the activity of acetylcholine esterase (53.01\%), AcP (31.06\%), AkP (20.99), $\alpha$-Carboxyl (64.17\%), and $\beta$-Carboxyl (47.41\%) was found with $30 \%$ concentration of $A$. indica extract. A maximum decrease in the activity of AChE $(60.31 \%)$ by C. murale, AcP (31.06\%) by E. prostrata, AkP (25.55\%) by F. indica, and $\alpha$-Carboxyl (70.39) and $\beta$-Carboxyl (61.3\%) by E. prostrata was recorded at $30 \%$ concentrations, respectively. It was found that E. prostrata induced maximum reduction in the enzymatic activity of $D$. melanogaster larvae (Table 6).

Table 7 shows the percent inhibition of the enzymatic activity of $D$. melanogaster larvae by the combination of E. prostrata and Bti after 72 hours. The concentrations of $250 \mathrm{ppm}$ caused maximum reduction in the activity of Ache, AcP, AkP, $\alpha$-Carboxyl, and $\beta$-Carboxyl enzymes. It can be observed that enzyme inhibition was increased with increased concentration of E. prostrata and Bti (Table 7).

3.2. Phytochemical Analysis of Plant Extracts. The whole weed plants extracted in petroleum ether as solvent were investigated for their phytochemical components, that is, flavonoids, saponins, tannins, steroids, cardiac glycosides, alkaloids, anthraquinones, and terpenoids. The qualitative tests revealed the presence of flavonoids $(\mathrm{Fl})$, saponins $(\mathrm{Sa})$, and alkaloids (Al) in all tested extracts. P. hysterophorus and F. indica showed no sign of tannins (Tn), while steroids (St) were absent in E. prostrata. Cardiac glycosides (CG) were not detected in the extract of $F$. indica. Anthraquinones (Anth) were found absent in C. murale. Terpenoids were not observed in E. prostrata and C. murale (Table 8).

3.3. Fourier Transform Infrared Spectroscopy (FTIR). Fourier transform infrared spectroscopy (FTIR) is a powerful molecular spectroscopic tool which helps in both quantitative and qualitative analysis of diverse inorganic and organic compounds. It gives results in the form of absorption spectrum. Generally, FTIR looks at the vibration of functional groups present in organic molecules and explores the structural alterations as the function of shifts in wave number [35]. The FTIR spectroscopic analysis of $E$. prostrata extract revealed the presence of various chemical constituents (Figure 1). The absorption at 3341.48 shows the presence of polyphenolic 


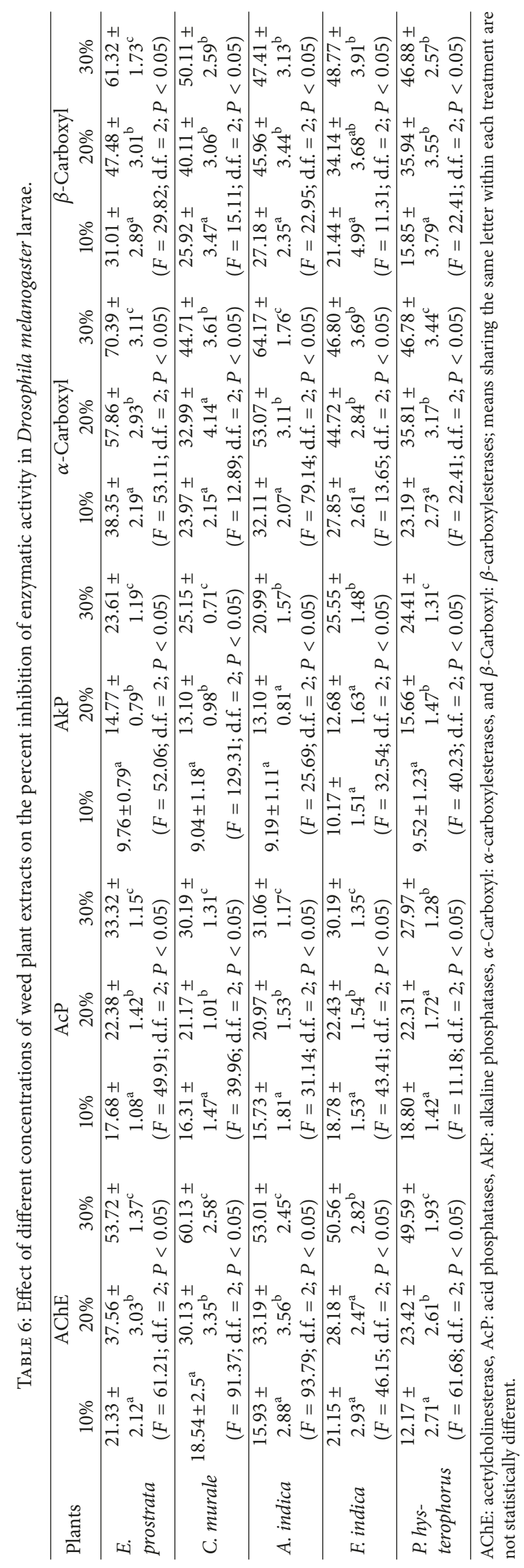


TABLE 7: Percent inhibition of enzyme activity in Drosophila melanogaster larvae using different concentrations of Bti at $30 \%$ concentrations of Euphorbia prostrata.

\begin{tabular}{|c|c|c|c|c|c|}
\hline Concentrations & $\begin{array}{c}\text { A Ch E } \\
(F=25.92 ; \text { d.f. }=5 ; \\
P<0.05)\end{array}$ & $\begin{array}{c}\text { AcP } \\
(F=24.23 ; \text { d.f. }=5 ; \\
P<0.05)\end{array}$ & $\begin{array}{c}\text { AkP } \\
(F=53.78 ; \text { d.f. }=5 \\
P<0.05)\end{array}$ & $\begin{array}{c}\alpha \text {-Carboxyl } \\
(F=10.68 ; \text { d.f. }=5 \\
P<0.05)\end{array}$ & $\begin{array}{c}\beta \text {-Carboxyl } \\
(F=6.79 ; \text { d.f. }=5 ; \\
P<0.05)\end{array}$ \\
\hline Water + food & $3.69 \pm 1.16^{\mathrm{a}}$ & $0.59 \pm 1.22^{\mathrm{a}}$ & $0.00 \pm 0.67^{\mathrm{a}}$ & $0.00 \pm 0.66^{\mathrm{a}}$ & $0.61 \pm 0.90^{\mathrm{a}}$ \\
\hline Water $+B t i+$ food & $6.12 \pm 0.83^{\mathrm{a}}$ & $0.96 \pm 1.11^{\mathrm{b}}$ & $0.85 \pm 0.76^{\mathrm{a}}$ & $1.07 \pm 1.12^{\mathrm{a}}$ & $1.57 \pm 1.16^{\mathrm{a}}$ \\
\hline $\begin{array}{l}\text { Euphorbia prostrata + water }+ \\
\text { food }\end{array}$ & $53.72 \pm 1.37^{\mathrm{c}}$ & $33.32 \pm 1.15^{\mathrm{c}}$ & $23.61 \pm 1.19^{c}$ & $70.39 \pm 3.11^{c}$ & $61.32 \pm 1.73^{\mathrm{c}}$ \\
\hline Euphorbia prostrate + Bti $10 \mathrm{ppm}$ & $11.57 \pm 1.20^{\mathrm{bc}}$ & $7.10 \pm 1.32^{\mathrm{ac}}$ & $7.10 \pm 1.32^{\mathrm{ac}}$ & $2.78 \pm 1.07^{\mathrm{a}}$ & $3.64 \pm 1.33^{\mathrm{a}}$ \\
\hline Euphorbia prostrate + Bti $50 \mathrm{ppm}$ & $14.12 \pm 1.38^{\mathrm{cd}}$ & $8.13 \pm 1.41^{\mathrm{a}}$ & $5.59 \pm 1.45^{\mathrm{b}}$ & $2.56 \pm 1.37^{\mathrm{a}}$ & $3.03 \pm 1.38^{\mathrm{a}}$ \\
\hline $\begin{array}{l}\text { Euphorbia prostrata }+ \text { Bti } \\
100 \mathrm{ppm}\end{array}$ & $16.67 \pm 0.97^{\mathrm{de}}$ & $10.77 \pm 1.72^{\mathrm{a}}$ & $10.70 \pm 1.69^{c}$ & $7.27 \pm 1.77^{\mathrm{a}}$ & $6.67 \pm 1.01^{\mathrm{ab}}$ \\
\hline $\begin{array}{l}\text { Euphorbia prostrata }+B t i \\
250 \mathrm{ppm}\end{array}$ & $20.23 \pm 1.38^{\mathrm{e}}$ & $16.47 \pm 2.08^{\mathrm{d}}$ & $19.22 \pm 3.14^{\mathrm{d}}$ & $15.17 \pm 3.15^{\mathrm{b}}$ & $13.33 \pm 3.14^{\mathrm{b}}$ \\
\hline
\end{tabular}

AChE: acetylcholinesterase, AcP: acid phosphatases, AkP: alkaline phosphatases, $\alpha$-Carboxyl: $\alpha$-carboxylesterases, and $\beta$-Carboxyl: $\beta$-carboxylesterases; means sharing the same letter within each treatment are not statistically different.

TABLE 8: Phytochemical constituents of petroleum ether extracts of selected weed plants.

\begin{tabular}{lccccccccc}
\hline \multirow{2}{*}{ Sr. number } & \multirow{2}{*}{ Weed plants } & Fl & Sa & Tn & St & CG & Al & Anth & Ter \\
\hline 1 & E. prostrata & + & + & + & - & + & + & + \\
2 & C. murale & + & + & + & + & + & + & - \\
3 & A. indica & + & + & + & + & + & + & + \\
4 & F. indica & + & + & - & + & - & + & + \\
5 & P. hysterophorus & + & + & - & + & + & + & + \\
\hline
\end{tabular}

Fl: flavonoids, Sa: saponins, Tn: tannins, St: steroids, CG: cardiac glycosides, Al: alkaloids, Anth: anthraquinones, and Ter: terpenoids; +: positive; -: negative.

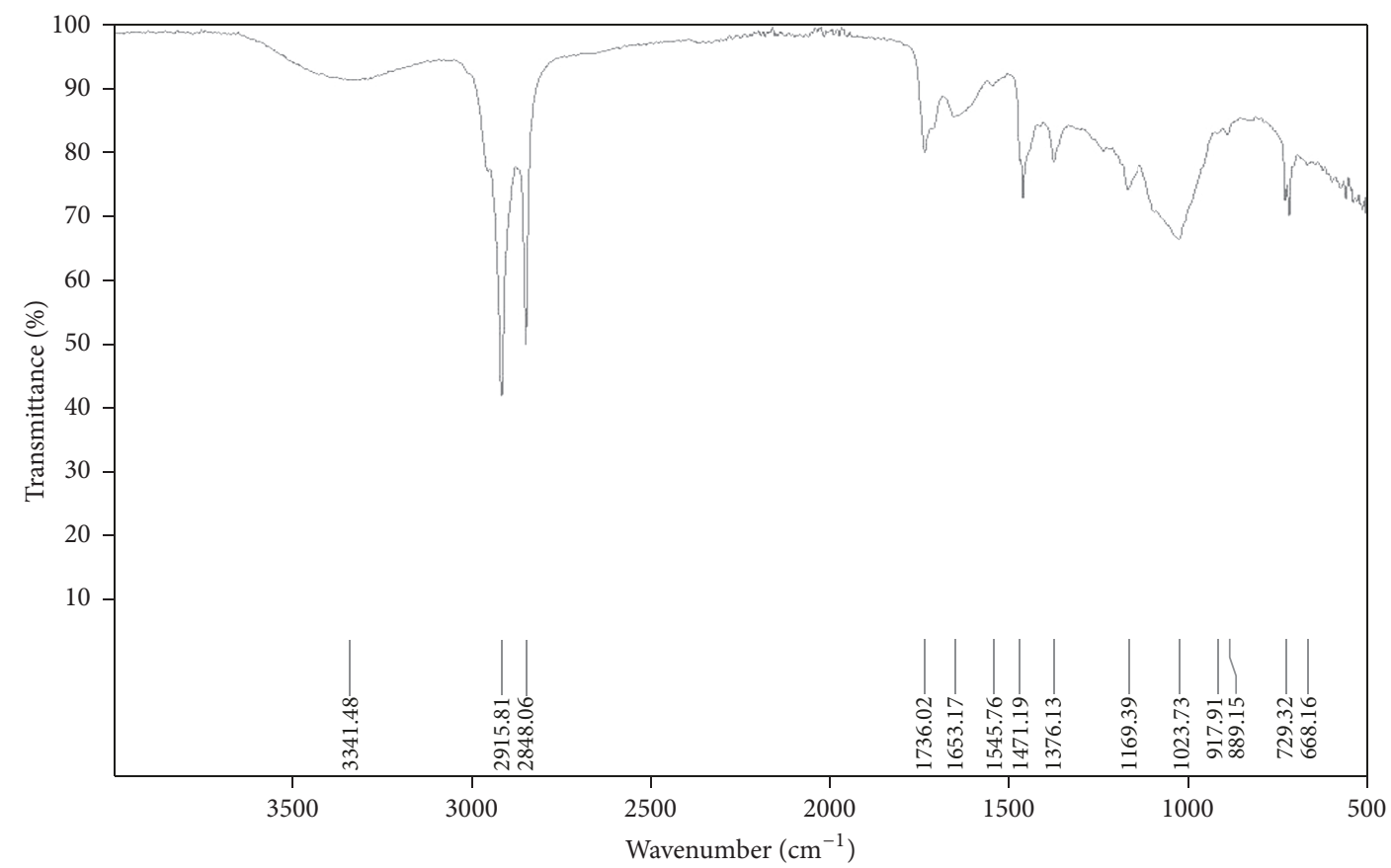

FIGURE 1: FTIR spectrum of Euphorbia prostrata. The spectrum shows a range of 4000 to $500 \mathrm{~cm}^{-1}$ wave number (along $x$-axis) and the function of \% transmittance (along $y$-axis). Following peaks can be observed: $2915.81 \mathrm{~cm}^{-1} \mathrm{CH}$ group stretching due to $\mathrm{CH}_{3}, 1736.02 \mathrm{~cm}^{-1}$ $\mathrm{C}=\mathrm{O}$ stretching, $1376.13 \mathrm{~cm}^{-1} \mathrm{C}-\mathrm{N}$ bond vibration, $1169.39 \mathrm{~cm}^{-1} \mathrm{C}-\mathrm{O}$ bond vibration, and $729.32 \mathrm{~cm}^{-1} \mathrm{C}-\mathrm{X}$ bond vibration. 


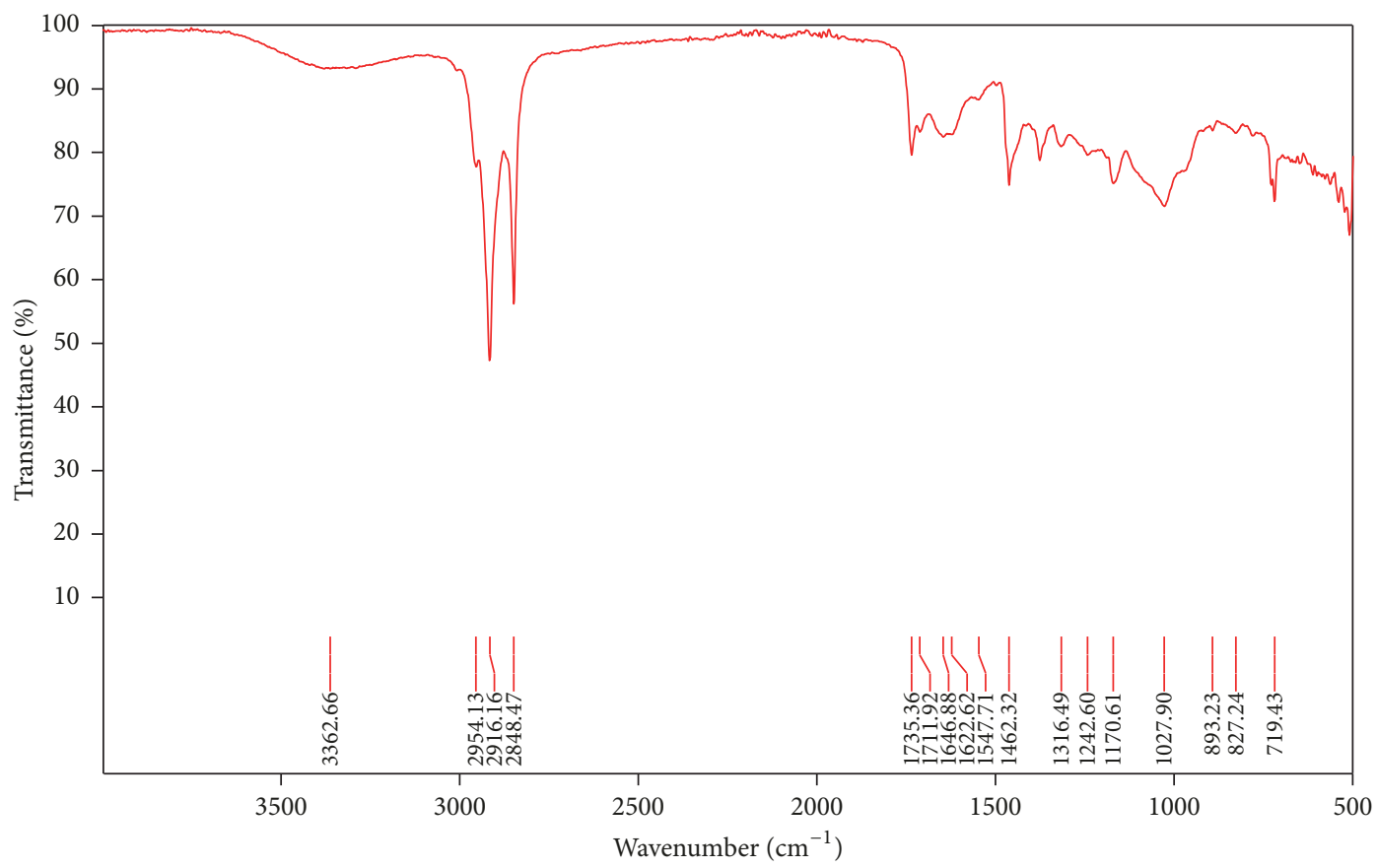

FIGURE 2: Full FTIR spectrum of Chenopodium murale. The spectrum shows a range of 4000 to $400 \mathrm{~cm}^{-1}$ wave number (along $x$-axis) and the function of \% transmittance (along $y$-axis). Following peaks were observed: $1027.90 \mathrm{~cm}^{-1}$ aromatic in-plane C-H bending, $1622.62 \mathrm{~cm}^{-1}$ carbonyl $(\mathrm{C}=\mathrm{O})$ group, $2916.16 \mathrm{~cm}^{-1}$ asymmetric $\mathrm{CH}_{2}$ stretching, and $3363.66 \mathrm{~cm}^{-1} \mathrm{O}-\mathrm{H}$ stretching. It reveals the presence of phenolics compounds having carboxylic acids.

compounds due to presence of flavonoids. The intense absorption bands at $2915.81 \mathrm{~cm}^{-1} \mathrm{CH}$ group stretching due to $\mathrm{CH}_{3}$ and $1736.02 \mathrm{~cm}^{-1}$ represent $\mathrm{C}=\mathrm{O}$ stretching. The absorption band at $1376.13 \mathrm{~cm}^{-1}$ denotes the presence of $\mathrm{C}-\mathrm{N}$ bond vibration possibly due to $\mathrm{NH}_{2},=\mathrm{NH}$, or $\equiv \mathrm{N}$ absorption. The bands at $1169.39 \mathrm{~cm}^{-1}$ show $\mathrm{C}-\mathrm{O}$ bond vibration (carbonyl group) and $729.32 \mathrm{~cm}^{-1} \mathrm{C}-\mathrm{X}$ bond vibration due to alcoholic or phenolic compounds. The presence of phenolic compounds is also shown in Figure 2 for Chenopodium murale.

\section{Discussion}

The chemical insecticides have been considered as the good option for the control of insect pests; however, chemical use causes adverse effects to the biotic and abiotic environment. The choice of new insecticides that meet the requirements of economy, safety, and efficacy highlights the objectivity of farmers. Thus, nowadays biopesticides are being used to control various insect pests $[4,21,37]$. Biopesticides are a type of pesticide derived from natural materials like animals, plants, bacteria, viruses, and certain minerals. The plant kingdom has been recognized as the most efficient producer of chemical compounds, synthesizing many products that are used to defend plants against different pests [38]. Moreover, it has been reported that Bacillus thuringiensis israelensis and pseudomonas can be successfully used against insect pests including Drosophila [6]. Thus, the present study was designed in order to find out a potent weed plant in combination with Bti strain to be used for the control of flies as well as a guideline model for other insect pests.

Four different weed plants extracts, namely, E. prostrata, C. murale L, F. indica, and P. hysterophorus, were used along with $A$. indica (Neem plant) as a reference to observe their efficacy against Drosophila melanogaster. This current study signifies the use of unwanted plants which are considered as pests themselves. It is also worth mentioning that these weed plants act as a rich source of different bioactive compounds that can be biodegraded into nontoxic products which are potentially suitable for integrated pest management [37]. In fact, many researchers reported the effectiveness of plant essential oils and extracts and described the plant based compounds from $A$. indica due to which this plant was taken as a reference for the current research work [9, 39-41]. E. prostrata showed $51.64 \%$ mortality at $30 \%$ concentration after 72 hours and showed significant results against Drosophila flies.

It has been already reported that methanolic plant extracts caused mortality in fruit fly, D. melanogaster [3]. Similarly, the ovicidal and larvicidal activity of essential oils from rosewood and garlic against Plutella xylostella was reported [42]. Subsequent studies also showed that $A$. indica caused significant mortality in D. melanogaster [21]. However, in the present study, E. prostrata and P. hysterophorus did not show significant difference of mortality from $A$. indica both at 24 and at $48 \mathrm{hrs}$ (data not shown). Overall E. prostrata produced highly significant results compared to other three weed plants. Therefore, it was selected for further trials with $B t i$. Different ppm solutions of Bti were used and it was found 
that increasing the concentration of Bti resulted in increased mortality \%age. The combination trial of E. prostrata plus Bti when compared with control trials showed more mortality compared to individual weed plant E. prostrata extract and Bti. Importantly, $100 \%$ mortality was found with E. prostrata extract plus Bti. $\mathrm{LC}_{50}$ values calculated through Probit Analysis showed that combination of $E$. prostrata extract and $B t i$ $250 \mathrm{ppm}$ has significant results ( $P$ values 0.00$)$ (Tables 4 and $5)$.

Plant allelochemicals are useful in increasing the effect of biological control agents $[1,43]$. Since these plant chemicals are less expensive, easily biodegradable, and considered as highly suitable for integrated pest management programs being active against a number of insect pests, so they could lead to developing safer insect pest control agents [9-11, 13, 37]. These findings are in agreement with Sultana et al. [9]. They investigated the efficiency of petroleum ether extracts of weed plants, Euphorbia prostrata and Chenopodiastrum murale for the control of Trogoderma granarium. They found relatively high rate of larval mortality after 6 days with $10 \%, 20 \%$, and $30 \%$ extract concentrations. However, at $30 \%$ concentration, the corresponding mortality rates induced by E. prostrata and C. murale are high.

The petroleum ether extract of weed plants also induced enzyme inhibitory activity against $D$. melanogaster. The inhibitory activity of acetylcholinesterase enzyme was reported due to insecticides [44]. In addition, it was also described that acetylcholinesterase is the most sensitive enzyme affected by the insecticides [45]. Furthermore, the inhibition of esterase activity was reported in insects by plant products [46]. Subsequently, a significant reduction in the activity of acetylcholinesterase, total esterase (TE), and arylesterase (AE) was also described in 4th instar larvae of $T$. granarium treated for $80 \mathrm{~h}$ exposed period with Phosphine [47].

Similarly, the biochemical effects of seven culinary and medicinal plant oils were described, namely, garlic (Allium sativum L.), onion (Allium cepa L.), olive (Olea europaea L.), rosemary (Rosmarinus officinalis L.), sunflower (Helianthus annuus L.), peppermint (Mentha piperita L.), and camphor (Eucalyptus globulus) against Trogoderma granarium 4th instar larvae [25]. A decrease in glucose and lipid contents and higher protein contents were observed in the treated larvae. It was also found that these plant oils caused less alkaline phosphatase (AKP) activity and low acid phosphatase (ACP) content. Cholinesterase was found to be increased whereas alanine aminotransferase (ALT) and aspartate aminotransferase (AST) activity in 4th instar larvae were found to be decreased. The current results are also in accordance with [48] who reported that Artemisia annua extract inhibited the AChE activity in higher doses in treated Sunn pest.

The current findings of IR spectra of E. prostrata are in accordance to the previously reported analysis [49]. The phytochemical screening revealed the presence of flavonoids, terpenoids, and tannins. Moreover, IR spectra showed the $\mathrm{OH}, \mathrm{CH}$ stretching and $\mathrm{C}=\mathrm{O}, \mathrm{C}=\mathrm{C}, \mathrm{NO}_{2}, \mathrm{C}-\mathrm{N}, \mathrm{C}-\mathrm{O}$ stretching, respectively. Subsequently, FTIR was used to analyze the various components from different medicinal plants [36]. IR spectra showed the presence of phenolic compounds which were further evaluated for their antioxidant activity. The peak values through FTIR analysis of Euphorbia prostrata indicated the presence of phenolic compounds which are consistent with the previous findings [50]. They obtained similar IR spectra corresponding to different functional groups with similar band stretching. Thus, on the basis of absorption values, the presence of polyphenolics $(-\mathrm{OH})$ and flavonoid type compounds was confirmed in the methanolic extract. The plants which showed significant results in the current study contain mainly flavonoids, tannins, and phenolic compounds. It has been reported that these compounds can be potentially used for the control of insect pests of various crops [37].

Although the efficacy of phytochemicals from various plants to evaluate the toxicity has been reported in $D$. melanogaster, however, efficacy of Euphorbia prostrata and their effect on enzymatic activity in D. melanogaster have not been reported yet. Thus, the present study is the first report to describe these parameters. In future, further studies can be conducted to extract and characterize the potential phenolic compound found in E. prostrata to use in the insect pest management program.

\section{Conclusion}

Euphorbia prostrata and Parthenium hysterophorus extracts showed toxicity against Drosophila melanogaster. However, based on $\mathrm{LC}_{50}$ values ( $P$ values), $E$. prostrata weed plant extract was used along with $B t i$ for further trials and highest mortality of $D$. melanogaster was found. It was also found that $E$. prostrate induced maximum reduction in the enzymatic activity of AChE, AcP AkP, $\alpha$-Carboxyl, and $\beta$-Carboxyl in D. melanogaster larvae. Phytochemical analysis showed the presence of flavonoids, saponins, tannins, steroids, cardiac glycosides, alkaloids, anthraquinones, and terpenoids. Moreover, FTIR analysis showed that $E$. prostrata contains phenolic compounds which have been reported to show insecticidal activity. E. prostrata plant is easily available in Pakistan and its extract could be greatly used to control fruit flies. In future, further studies are needed to extract and characterize the particular potential phenolic compound found in E. prostrata to use in insect pest management programs.

\section{Conflicts of Interest}

The authors declare that there are no conflicts of interest.

\section{Acknowledgments}

The facilities and support provided by the Department of Zoology, Government College University Faisalabad are highly acknowledged.

\section{References}

[1] J. Abraham, A. Zhang, S. Angeli et al., "Behavioral and Antennal Responses of Drosophila suzukii (Diptera: Drosophilidae) to Volatiles from Fruit Extracts," Environmental Entomology, vol. 44, no. 2, pp. 356-367, 2015. 
[2] I. Montenegro, L. Pino, E. Werner et al., "Comparative study on the larvicidal activity of drimane sesquiterpenes and nordrimane compounds against drosophila melanogaster til-til," Molecules, vol. 18, no. 4, pp. 4192-4208, 2013.

[3] S. Khan, C. N. T. Taning, E. Bonneure, S. Mangelinckx, G. Smagghe, and M. M. Shah, "Insecticidal activity of plantderived extracts against different economically important pest insects," Phytoparasitica, vol. 45, no. 1, pp. 113-124, 2017.

[4] A. J. Needham, M. Kibart, H. Crossley, P. W. Ingham, and S. J. Foster, "Drosophila melanogaster as a model host for Staphylococcus aureus infection," Microbiology, vol. 150, no. 7, pp. 2347-2355, 2004.

[5] H. Schmutterer, "Properties and potential of natural pesticides from the neem tree, Azadirachta indica," Annual Review of Entomology, vol. 35, no. 1, pp. 271-297, 1990.

[6] R. H. Ffrench-Constant and N. R. Waterfield, "Ground control for insect pests," Nature Biotechnology, vol. 24, no. 6, pp. 660661, 2006.

[7] B. Ahmad, Q. Jan, S. Bashir, M. Nisar, F. Shaheen, and M. Ahmad, "Pharmacological and biological investigations of Chenopodium murale Linn," Asian Journal of Plant Sciences, vol. 2, pp. 1107-1111, 2003.

[8] S. N. H. Naqvi and F. Parveen, "Toxicity and Residual Effect of Nerium indicum crude extract as compared with coopex against adults of Tribolium castaneum," Pakistan Journal of Entomology Karachi, vol. 6, pp. 35-44, 1991.

[9] K. Sultana, M. K. Zahoor, M. Sagheer et al., "Insecticidal activity of weed plants, Euphorbia prostrata and Chenopodiastrum murale against stored grain insect pest Trogoderma granarium Everts, 1898 (Coleoptera: Dermestidae)," Turkish Journal of Entomology, vol. 40, no. 3, pp. 291-301, 2016.

[10] D. A. Vázquez-Covarrubias, A. Jiménez-Pérez, F. CastrejónAyala, R. Figueroa-Brito, and R. M. Belmont, "Effects of five species of chenopodiaceae on the development and reproductive potential of Copitarsia decolora (Lepidoptera: Noctuidae)," Florida Entomologist, vol. 98, no. 1, pp. 80-85, 2015.

[11] M. Alkan, A. Gökçe, and K. Kara, "Antifeedant activity and growth inhibition effects of some plant extracts against larvae of Colorado potato beetle [Leptinotarsa decemlineata Say (Col: Chyrsomelidae)] under laboratory conditions," Turkiye Entomoloji Dergisi, vol. 39, no. 4, pp. 345-353, 2015.

[12] V. J. Cvetković, T. L. Mitrović, B. Jovanović et al., "Toxicity of dimethyl sulfoxide against Drosophilamelanogaster," Biologica. Nyssana, vol. 6, no. 2, pp. 91-95, 2015.

[13] M. Sagheer, M. Hasan, A. Majid, Q. Ali, M. I. Shahid, and K. Ali, "Repellent effect of four medicinal plant extracts to Trogoderma granariumEverts (Coleoptera: Dermestidae)," Journal of Global Innovation in Agricultural and Social Sciences, vol. 1, pp. 9-11, 2013.

[14] R. Qureshi, A. Waheed, M. Arshad, and T. Umbreen, "Medicoethnobotanical inventory of Tehsil Chakwal, Pakistan," Pakistan Journal of Botany, vol. 41, no. 2, pp. 529-538, 2009.

[15] M. S. Abdel-Aziz, M. S. Shaheen, A. A. El-Nekeety, and M. A. Abdel-Wahhab, "Antioxidant and antibacterial activity of silver nanoparticles biosynthesized using Chenopodium murale leaf extract," Journal of Saudi Chemical Society, vol. 18, no. 4, pp. 356-363, 2014.

[16] S. Patel, "Harmful and beneficial aspects of Parthenium hysterophorus: an update," 3 Biotech, vol. 1, no. 1, pp. 1-9, 2011.

[17] A. I. Maishi, P. K. S. Ali, S. A. Chaghtai, and G. Khan, "A proving of Parthenium hysterophorus, L," British Homoeopathic Journal, vol. 87, pp. 17-21, 1998.
[18] P. C. Gupta, N. Sharma, and C. V. Rao, "A review on ethnobotany, phytochemistry and pharmacology of Fumaria indica (Fumitory)," Asian Pacific Journal of Tropical Biomedicine, vol. 2, no. 8, pp. 665-669, 2012.

[19] G. Vales, E. Demir, B. Kaya, A. Creus, and R. Marcos, "Genotoxicity of cobalt nanoparticles and ions in Drosophila," Nanotoxicology, vol. 7, no. 4, pp. 462-468, 2013.

[20] M. Miyazawa, K. Yoshio, Y. Ishikawa, and H. Kameoka, "Insecticidal Alkaloids against Drosophila melanogaster from Nuphar japonicum DC," Journal of Agricultural and Food Chemistry, vol. 46, no. 3, pp. 1059-1063, 1998.

[21] S. I. Anjum, M. J. Yousf, S. Ayaz, and B. S. Siddiqui, “Toxicological evaluation of chlorpyrifos and Neem extract (Biosal B) against 3RD instars larvae of Drosophila melanogaster," Journal of Animal and Plant Sciences, vol. 20, no. 1, pp. 9-12, 2010.

[22] M. K. Zahoor, F. Batool, S. Nasir et al., "Population dynamics and genetic homogeneity in natural populations of Drosophila melanogaster from Faisalabad, Pakistan," Iranian Journal of Science \& Technology, vol. 41, no. 2, pp. 277-285, 2017.

[23] F. Batool, "Studies on the genetic variations in natural populations of Drosophila melanogaster using RAPD and Microsatellite markers," Tech. Rep., Govt. College University, Faisalabad, Pakistan, 2012.

[24] S. Sumroiphon, C. Yuwaree, C. Arunlertaree, N. Komalamisra, and Y. Rongsriyam, "Bioactivity of citrus seed for mosquitoborne diseases larval control.," The Southeast Asian Journal of Tropical Medicine and Public Health, vol. 37, pp. 123-127, 2006.

[25] M. W. Younes, S. E. Othman, M. A. Elkersh, N. S. Youssef, and G. A. Omar, "Effect of seven plant oils on some biochemical parameters in Khapra beetle Trogoderma granarium Everts (Coleoptera: Dermestidae)," The Egyptian Journal of Experimental Biology, vol. 7, no. 1, pp. 53-61, 2011.

[26] K. van Asperen, "A study of housefly esterases by means of a sensitive colorimetric method," Journal of Insect Physiology, vol. 8, no. 4, pp. 401-IN3, 1962.

[27] K. Asakura, "Phosphatase activity in the larva of the euryhaline mosquito, Aëdes togoi Theobald, with special reference to seawater adaptation," Journal of Experimental Marine Biology and Ecology, vol. 31, no. 3, pp. 325-337, 1978.

[28] J. B. Harborne, Phytochemical Methods, vol. 49, Chapman and Hall, Ltd, London, 188 edition, 1973.

[29] G. E. Trease and W. C. Evans, Pharmacognsy, Brailliar Tiridel Can. Macmillian publishers, 11th edition, 1989.

[30] A. Sofowara, Medicinal Plants and Traditional Medicine in Africa, Spectrum Books Ltd, Ibadan, Nigeria, 1993.

[31] A. A. Siddiqui and M. Ali, Practical Pharmaceutical Chemistry, CBS Publishers and Distributors, New Delhi, India, 1997.

[32] T. S. Roopashree, R. Dang, R. H. Shobha Rani, and C. Narendra, "Antibacterial activity of antipsoriatic herbs: Cassia tora, Momordica charantia and Calendula officinalis," International Journal of Applied Research in Natural Products, vol. 1, no. 3, pp. 20-28, 2008.

[33] K. R. Khandelwal, Practical Pharmacognosy Techniques and Experiments, Nirali Parkashan, Pune, India, 20th edition, 2004.

[34] M. A. Iyengar, Study of Crude Drugs, Manipal Power Press, 8th edition, 1995.

[35] S. S. Binac, F. Afshan, T. Gulzar, and R. Sultana, "Tetracyclic triterpenoids from the leaves of Azadirachtaindica and their insecticidal activities," Chemical and Pharmaceutical Bulletin, vol. 51, no. 4, pp. 415-417, 2003. 
[36] M. J. Kassim, M. H. Hussin, A. Achmad, N. H. Dahon, T. K. Suan, and H. S. Hamdan, "Determination of total phenol, condensed tannin and flavonoid contents and antioxidant activity of Uncaria gambir extracts," Indonesian Journal of Pharmacy, vol. 22, no. 1, pp. 50-59, 2011.

[37] A. P. C. Alves, A. D. Corrêa, D. S. Alves, A. A. Saczk, J. B. R. Lino, and G. A. Carvalho, "Toxicity of the phenolic extract from jabuticabeira (Myrciaria cauliflora (Mart.) O. Berg) fruit skins on Spodoptera frugiperda," Chilean Journal of Agricultural Research, vol. 74, no. 2, pp. 200-204, 2014.

[38] M. B. Isman and Y. Akhtar, "Plant natural products as a source for developing environmentally acceptable insecticides," in Insecticides Design Using Advanced Technologies, I. Shaaya, R. Nauen, and A. R. Horowitz, Eds., pp. 235-248, Springer, Berlin, Germany, 2007.

[39] A. Amer and H. Mehlhorn, "Repellency effect of forty-one essential oils against Aedes, Anopheles, and Culex mosquitoes," Parasitology Research, vol. 99, no. 4, pp. 478-490, 2006.

[40] F. Abdel-Ghaffar, M. Semmler, K. Al-Rasheid, S. Klimpel, and H. Mehlhorn, "Efficacy of a grapefruit extract on head lice: A clinical trial," Parasitology Research, vol. 106, no. 2, pp. 445-449, 2010.

[41] M. A. Apel, P. Vasudevan, M. Tandon, and R. K. Razdan, "Larvicidal and mosquito repellent action of peppermint (Menthapiperita) oil," Bioresearch Technology, vol. 71, pp. 267-271, 2000.

[42] J. S. Sangha, T. Astatkie, and G. C. Cutler, "Ovicidal, larvicidal, and behavioural effects of some plant essential oils on diamondback moth (Lepidoptera: Plutellidae)," The Canadian Entomologist, vol. 149, no. 5, pp. 639-648, 2017.

[43] S. S. Nathan, K. Kalaivani, and K. Murugan, "Effects of neem limonoids on the malaria vector Anopheles stephensi Liston (Diptera: Culicidae)," Acta Tropica, vol. 96, no. 1, pp. 47-55, 2005.

[44] P. Menozzi, M. A. Shi, A. Lougarre, Z. H. Tang, and D. Fournier, "Mutations of acetylcholinesterase which confer insecticide resistance in Drosophilamelanogaster populations," BMC Evolutionary, vol. 4, no. 1, 2004.

[45] I. Fremaux, S. Mazères, A. Brisson-Lougarre, M. Arnaud, C. Ladurantie, and D. Fournier, "Improvement of Drosophila acetylcholinesterase stability by elimination ofa free cysteine," BMC Biochemistry, vol. 3, article no. 1, pp. 1-5, 2002.

[46] S. S. Nathan, M. Y. Choi, H. Y. Seo, C. H. Paik, K. Kalaivani, and J. D. Kim, "Effect of azadirachtin on acetylcholinesterase (AChE) activity and histology of the brown planthopper Nilaparvata lugens," Ecotoxicology and Environmental Safety, vol. 70, no. 2, pp. 244-250, 2008.

[47] S. A. Falak and A. R. Shakoori, "Phosphine Induced Changes in Various Esterase levels in 4th Instar Larvae of Trogoderma granarium," Pakistan Journal of Zoology, vol. 36, no. 4, pp. 257260, 2004.

[48] A. Zibaee and A. Bandani, "A study on the toxicity of a medicinal plant, Artemisia Annua L. (Asteracea) extracts to the sunn pest, eurygaster integriceps puton (Hemiptera: Scutelleridae)," Journal of Plant Protection Research, vol. 50, no. 1, pp. 79-85, 2010.

[49] M. Qaisar, S. N. Gilani, S. Farooq, A. Rauf, R. Naz, and P. S. Shaista, "Preliminary comparative phytochemical screening of euphorbia species," American-Eurasian Journal of Agricultural Environmental Sciences, vol. 12, no. 8, pp. 1056-1060, 2012.

[50] D. Kavitha, R. Parvatham, and P. R. Padma, "Assessment of Trianthema portulacastrum for its antimicrobial potential and investigation of their phytochemicals using HPTLC, GC-MS, and IR," International Journal of Pharmacy and Pharmaceutical Sciences, vol. 6, no. 1, p. 675, 2014. 


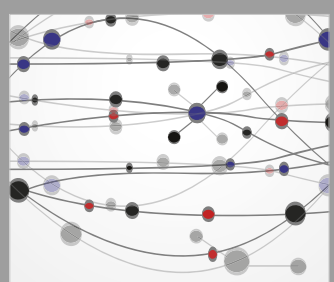

The Scientific World Journal
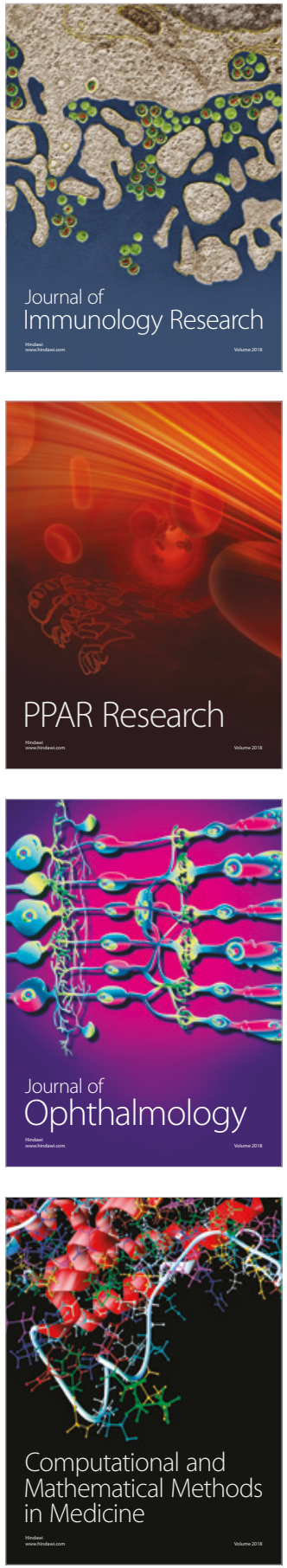

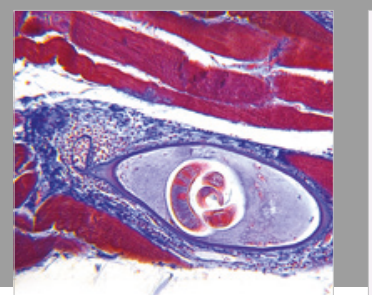

Gastroenterology Research and Practice

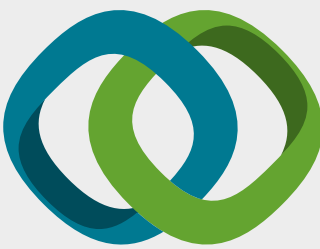

\section{Hindawi}

Submit your manuscripts at

www.hindawi.com
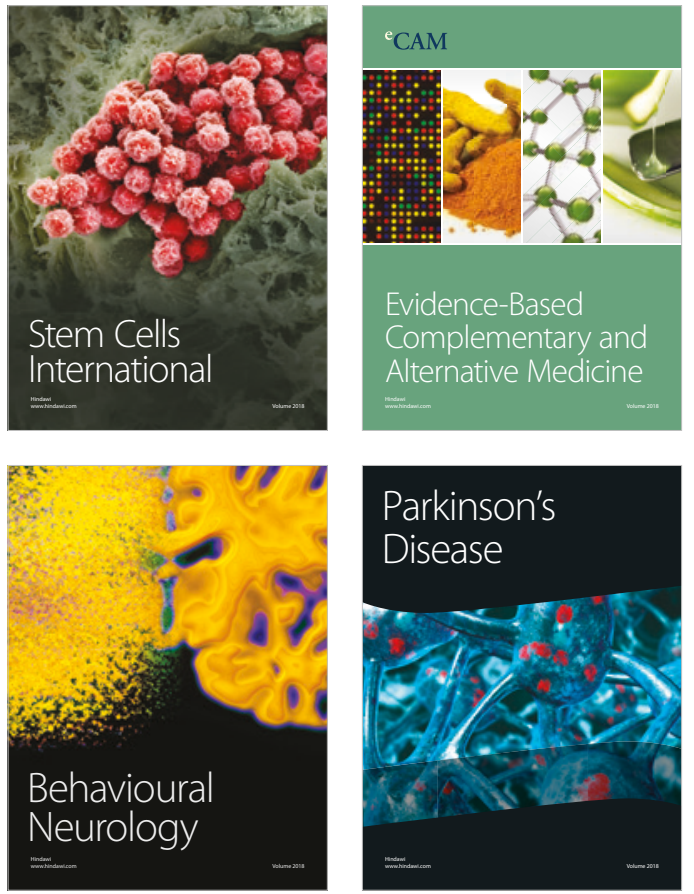

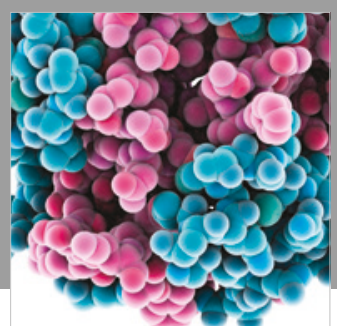

ournal of

Diabetes Research

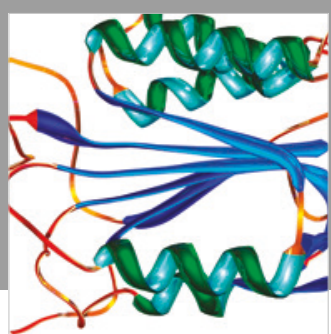

Disease Markers
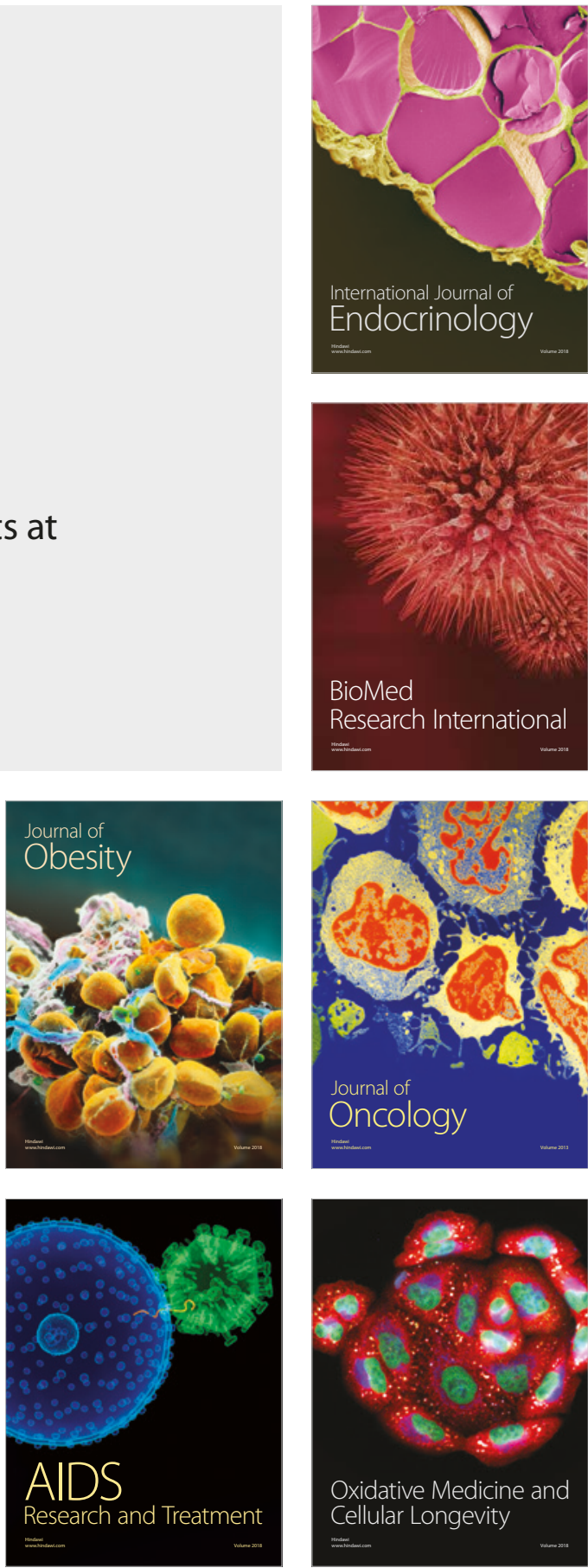